\title{
TWEETING ON CATALONIA'S INDEPENDENCE: THE DYNAMICS OF POLITICAL DISCUSSION AND GROUP POLARISATION
}

\author{
Joan Balcells :: Albert Padró-Solanet
}

IZVORNI ZNANSTVENI RAD / DOI: 10.20901/ms.7.14.9 / PRIMLJENO: 07.03.2016.

\begin{abstract}
This article provides evidence in favour of social media serving as facilitators of public deliberation, in contrast with the hypothesis that emphasises the dominance of the "echo chamber" effect. It focuses on conversational interactions on Twitter between supporters from opposite sides in a potentially highly polarised political issue, i.e. the debate on the independence of Catalonia, which is used as a case study. Methodologically we rely on a random sample of communications on the Twitter reply network, involving for and against independence supporters. Remarkably, despite the tendency of forming homophilic networks, we find that communication across political lines is relatively frequent. Furthermore, heterogeneous conversations (where opposing sides are engaged in a dialogue) tend to be significantly longer than homogenous ones (where all participants share the same view), which can be seen as a sign of genuine deliberation based on reasonably exchanging arguments between competing viewpoints.
\end{abstract}

\section{KEY WORDS}

SOCIAL MEDIA, TWITTER, PUBLIC OPINION, DELIBERATION, POLARISATION

Authors Note

Joan Balcells :: Faculty of Law and Political Science, Universitat Oberta de Catalunya,

Barcelona, Spain :: jbalcells@uoc.edu

Albert Padró-Solanet :: Faculty of Law and Political Science, Universitat Oberta de Catalunya, Barcelona, Spain :: apadro_solanet@uoc.edu

Authors are particularly thankful to Miguel Ángel Domingo for his help in the process of data collection and systematisation. 


\section{INTRODUCTION}

Traditionally, the processes of secession from a state tend to be highly polarising as they imply redefining the social contract that bounds citizens together in a political community. Referenda on secession, like those in Scotland and Quebec, have been accompanied by intense debates and have attracted massive levels of political involvement and participation. However, the case of Catalonia is quite peculiar, as the debate has not formally taken place as of yet. The conflict has not been channelled officially through a political discussion on the pros and cons of independence in the setting of a referendum campaign, nor has it lead to a process of political negotiation, but instead finds itself in a cul-de-sac. The debate is actually taking place among citizens and has found in social media a space for confronting arguments and ideas.

This case provides a singular scenario in which to understand the dynamics of deliberation on social media (and specifically on Twitter) between two opinion communities who are highly attentive and mobilised over an issue. We assume that participants in this debate will tend to form homogenous groups according to their political preferences. Assuming "homophily" - i.e. the propensity to group oneself together with similar people (Lazarsfeld et al., 1954; McPherson et al., 2001; DiPrete et al., 2011) - and taking into account the level of political polarisation implied by the issue under study, we expect individuals to cluster around two opposing poles, forming two segregated and clearly differentiated opinion communities. Taking this premise into account, we measure and describe both the level of interaction and the kind of communication - particularly, in terms of deliberative engagement - that take place on Twitter between these two poles.

Our research question is twofold. (1) How frequent is communication across political lines? The confrontation of opposing viewpoints is a necessary condition for public deliberation to occur, a principle encapsulated in the Latin phrase audi alteram partem. Without the interaction with the "other side", deliberation lacks one of its essential features, i.e. the possibility to test one's own arguments by exposing them to competing lines of reasoning and rationales (Fishkin, 1991; Mutz, 2006). However, communication across political lines of difference does not guarantee per se the potential benefits of public deliberation. This point leads to our second research question: (2) How is cross communication between poles characterised, and what is the dialogical quality of these communications? This question introduces a crucial nuance. Discussion between opposing sides of the debate can lead towards different results depending on how the other side is approached. It can lead towards more tense and irreconcilable positions (especially if based on insults, threats, etc.); but it can also lead towards recognition of the other side as a valid interlocutor, someone with whom it is possible to reasonably dialogue and exchange arguments in spite of disagreement. Public deliberation is expected to flourish only if this second kind of communication prevails. 


\section{THEORETICAL BACKGROUND}

Deliberation has become the "Holy Grail" of recent political science. From a theoretical point of view, it is expected that a discursive or deliberative public sphere will work as a kind of Hegelian tertium datur that can reconcile equality with liberty, unity with diversity, or the right of the majority with the right of the minority - i.e. all the contradictions that confront liberalism and radical democracy (Habermas, 1985). Normatively, ideal deliberation must be free - in a procedure that guarantees that each part is treated equally, formally and substantively - and reasoned, requiring the parties to state their reasons for advancing proposals and supporting or criticising them.

Following this logic, one line of research has operationalised the normative conditions of deliberation in order to develop indices of discourse quality (Steenbergen et al., 2003). Ideal and actual practices of deliberation can be thought as points in a continuum (Mansbridge, 1999; Dryzek, 2000). Despite lacking some logical and procedural requirements of the ideal Habermasian model, everyday deliberation that emerges in the real-world forms of communication might be able to achieve certain standards of quality, such as preference structuring and intersubjective rationality, that can be measured and analysed (Bächtiger et al., 2010).

The analysis of deliberation in digital environments has become a fertile and prolific field of research both theoretically and empirically. The new digital environment represents a step further in the empirical analysis of public deliberation, passing from a scarcity to an abundance of data. The Internet has not only widened the repertoire of communication tools in the hands of citizens but has also made interactions and information flows more available and transparent for researchers who study the dynamics of deliberation and public opinion. This has given rise to a plethora of studies that try to assess the quality of online deliberation as compared with face-to-face communication, taking into account the specificities of information and communication technologies (e.g. Stromer-Galley et al., 2015).

In contrast with deliberative spaces in controlled environments such as forums with moderation and personal identification requirements (Wright et al., 2007; Graham, 2008; e.g. Ruiz et al., 2011), social media like Twitter provide a more immediate and spontaneous way to communicate with other people. The emergence of debate in Twitter is driven by a market mechanism with no central direction or control, similar to what happens with informal talk between citizens, but with the possibility of potentially reaching unlimited audiences. These conditions make Twitter an interesting case to test how individuals freely engage in online conversation over a specific issue, whether deliberation tends to be encapsulated in "echo chambers" of like-minded individuals in homogenous groups or whether there is actual discussion across lines of political difference in heterogeneous groups as would be expected in a public-sphere-like environment. 


\section{Social media and public deliberation}

It is a matter of discussion whether social media communication increases the socalled "echo chamber" effect or whether it makes contact with dissimilar views more likely to occur. This research question has been a leitmotif in the literature on the political effects of the Internet on public opinion since the early development of the Internet as a communication tool (e.g. Dertouzos, 1991; Rheingold, 1993; Ess, 1996), although, with the widespread prevalence and success of social media and Web 2.0, it has certainly taken on a new dimension.

Social media can contribute to the formation of more balanced and judicious public opinion depending on whether they resemble an echo chamber or whether there is the experience and expectation of being challenged by rival opinions. Admittedly, actual or potential exposure to counterargument forces individuals to revise their own ideas, to consider the position of the other person, and to sharpen their arguments in order to build more persuasive and convincing claims (Holbert et al., 2010).

Our analysis regards the length of conversations as an indicator of deliberative engagement (cf. Gonzalez-Bailon et al., 2010), which captures the involvement of participants in a reciprocal exchange of arguments. Deliberative quality has been measured by a range of parameters derived from normative theories of deliberative democracy (Steenbergen et al., 2003; Stromer-Galley, 2007). Deliberative engagement points to the dimension of "reciprocity" (Graham et al., 2006) and provides a clear and robust measure to summarise the give-and-take of conversations between individuals. A lengthy conversation is a sign of genuine deliberation since it implicitly entails the recognition of the other as someone with whom it is worth spending time discussing an issue. A short conversation may indicate a lack of involvement with what is being said by other interlocutors. This may happen because of several reasons, e.g. the nonexistence of disagreement - which makes further elaboration of arguments unnecessary; or the abrupt interruption of the conversation due to an insult or a provocative statement.

\section{The analysis of Twitter}

Twitter's microblogging service has become an open and massive public marketplace to exchange opinions and views, with a series of distinctive particularities. Some of them tend to exacerbate exposure to likeminded information (e.g. the suggestions to follow users according to one's following profile), while others tend to facilitate contact with heterogeneous and opposing viewpoints (e.g. the hashtag, retweet and mention functions can help to easily circulate tweets across different networks).

Several studies have provided evidence of Twitter's twofold nature. In their analysis on the US left-right divide on Twitter, Michael Conover et al. (2011) find a clear difference between the retweet and the mention networks. Whereas the retweet network is highly polarised, with users clearly divided along partisan lines, the mention network appears to be more porous, with intense cross-interactions between the two poles. Other studies confirm that retweet interactions tend to be concentrated predominantly among 
users with similar ideological positions, transforming Twitter into an "echo-chamber environment" (Barberá, 2015). Sarita Yardi and Danah Boyd's (2010) analysis of the prochoice vs. pro-life debate showed that, despite a general tendency towards homophily, conversations between opposing views are far from being rare on Twitter. The level of homophily also seems to differ between the network of reciprocated followers and the non-reciprocated one, with the former being more homophilic than the latter (Colleoni et al., 2014).

Our research targets "reply interactions", which are the basis of Twitter conversations, instead of simply tweets or retweets. Reply interactions are the most similar to a dialogue on Twitter, as they are actually a response to a tweet posted by another user. Sending a reply presupposes that the user feels compelled to respond to a post by providing his or her point of view. By doing so, we are focusing the attention on a potential resource at the hands of users to potentially approach and interact with individuals with dissimilar ideas and points of view.

Conversations on Twitter imply the participation of two or more users who engage in a dialogical activity. Because they are public, these conversations' audience is potentially much wider than the individuals involved. The limit of 140 characters certainly conditions the structure of conversations and fixes certain rules in interactions. Twitter favours short sentences at the expense of paused, long, well-developed arguments (although links to blog posts or webpages can be added to provide additional information). Although these constraints can jeopardise the qualities expected in an ideal deliberative environment, Twitter has certain features that promote and potentiate dialogue. Anyone can respond to someone else's tweet regardless of her position, status or reputation and initiate a conversation. The costs of participating are relatively low, as writing a tweet is less demanding than developing elaborated and complex speeches or even writing a post or a comment on a blog. The space limitation also makes the exchange of opinions very agile and dynamic, forcing users to be concise and focused.

We distinguish two forms of communication (inter-group and intra-group), depending on whether they involve dialoguing with users with similar or dissimilar opinions. These two forms of communication can be associated with different functions. Intragroup communication is important to keep group cohesion and morale, share a sense of participating in a common endeavour, manage and solve internal disagreements and doubts, and reinforce their own position with new arguments and ideas, or with the re-elaboration of the old ones. Inter-group communications are instead oriented at responding to opposing views and have a stronger component of rivalry and competition. They can be a genuine effort to cross ideological and political lines to try to face the other side (by persuading, convincing, counter-arguing, attacking, defending, etc.), but some users can cross the lines simply to find easily beaten arguments or examples of what can be interpreted on one's own side as proof of the evilness or stupidity of the other side.

Excessive intra-group communication is usually associated with the "echo chamber" effect, as there is the exclusion of "the other side" (among others, Adamic et al., 2005; 
Yardi et al., 2010; Garrett et al., 2014). Either the exclusion of conflicting opinions or the social pressures inside the group can radicalise positions and lead towards higher levels of opinion polarisation (Sunstein, 2002). Nevertheless, polarisation can also be induced by inter-group interactions, depending on the terms of the communication between individuals on opposite sides of the debate. Admittedly, the tactic of the "gladiators" of both sides that search for repulsive examples of the enemy's arguments or behaviour can promote the polarisation of groups. This effect can also be cancelled paradoxically, when the gladiators share the rival arguments within one's group, they are also facilitating access to the complete arguments of the other side - because the architecture of social media makes it very easy to cross lines - and, therefore, they are facilitating exposure to counter-attitudinal information, even between the less-committed members of the group, which potentially can reduce polarisation.

\section{The debate on the independence of Catalonia}

The increasing discontent towards the Spanish political establishment, aggravated because of its inability to accommodate demands for self-government, has fuelled the desire for independence in Catalonia (Guibernau, 2013). Public opinion polls show that, in a relatively short period of time, citizens' political preferences in Catalonia have radically shifted towards more polarised positions between supporters of the status quo and supporters of a new independent state ${ }^{1}$. Part of this shift is physically visible in the streets of many Catalan towns and cities, where the number of pro-independence estelada flags has increased palpably as a sign of protest.

In contrast with the Scottish case, where political parties have played a major role, the debate on the independence of Catalonia has entered the political agenda because of persistent grassroots pressure and mobilisation, which started with a wave of unofficial consultations on independence at the local level (see Muñoz et al., 2013). The main Catalan political parties were uncomfortable and reluctant to address this issue directly, and did not lead the demands for an independent Catalan state until later on. The issue has become so pervasive in Catalan society that the main social and political actors have been forced to take sides on the debate. This situation has completely redefined the political landscape (e.g. Rico et al., 2014; Orriols et al., 2016), with the emergence of new political forces, the reinforcement of political parties focused on this cleavage and the split of mainstream political parties, which have so far sustained an ambiguous position, into pro- and anti-independence factions.

The organisation and mobilisation capacity of the pro-independence political movement has relied strongly on a combination of local support and network coordination through the Internet as a means of empowering collective action (such as campaigning, sourcing for financial support, organising demonstrations, etc.). It has had the capacity to mobilise a large number of individuals - the human chain across Catalonia was one of its more powerful icons. Though initially less organised, detractors of independence have

\footnotetext{
${ }^{1}$ According to survey data from the Centre d'Estudis d'Opinió $(2006,2016)$ support for independence has grown from $15 \%$ (July 2006) to $42 \%$ (July 2016), being the most preferred alternative in a four-option question including the options of becoming an 'independent state', becoming a 'state in a federal Spain', preserving the status of 'autonomous community' and being a 'region'. See surveys REO 358 and REO 826.
} 
also gathered support to campaign against secession, especially through the Internet, where they are increasingly active. However, they have had more difficulty in organising massive support. Unionists understand the situation as a clear manipulation of the real preferences of a substantial part of the Catalan population and claim to represent the "silent majority" of Catalans.

The debate is presently polarised around two political organisations: the Catalan National Assembly (ANC - Assemblea Nacional de Catalunya), in favour of a Catalan independent state, and the Catalan Civil Society (SCC - Societat Civil Catalana), which is against. Both of them have become nodal actors in their respective networks and actually work as a hub of communication among supporters and detractors of a new Catalan state.

\section{DATA AND METHODS}

\section{Samples}

Our dataset consists of a random selection of replies to someone else's tweet, sent by users who are following the ANC Twitter account (@assemblea), the SCC account (@ Societatcc) or both. The decision to follow either account has been regarded as an indicator of being interested in this political issue.

The dataset was constructed on a two-step process of sampling. First, we randomly selected a group of followers of ANC $(\mathrm{N}=2,000)$ and a group of followers of SCC $(\mathrm{N}=2,000)$, according to parameters of Twitter activity ${ }^{2}$. For a period of 15 days (between 21/04/2015 and 04/05/2015), we captured, via streaming, all tweets sent by these users. Second, we randomly selected a number of these tweets that happen to be replies. We sampled 1,500 replies, 750 from each group, to work with manageable data and to have more control over the content analysis.

Most analyses on Twitter are based on identifying the main hashtags (\#) of a particular debate as a means of gathering a collection of tweets (Small, 2011; Rambukkana, 2015). In our case of study, there are no hashtags shared by defenders of both sides (like the Scottish \#indyref), and, furthermore, the use of hashtags tends to be rather fragmented and circumstantial.

Alternatively, our analysis takes advantage of the fact that the two major accounts behave as hubs for each side of the debate. The first account belongs to the ANC, the association built with the specific purpose of mobilising support for independence. This account is older than the account of the SCC, created explicitly to bring together and coordinate the individuals and organisations that oppose independence and counter the pro-independence mobilisation. This age difference is explained by the reactive function

\footnotetext{
${ }^{2}$ We selected accounts according to the frequency of updated status per day, excluding excessively productive accounts (i.e. those that belong to the first percentile) in order to eliminate outliers. In the case of ANC, $75 \%$ of the accounts were selected from among users that belong to the first quartile in the indicator of updated status per day, and the other $25 \%$ from the rest. As for the sample of SCC followers, $75 \%$ of the accounts were selected from among users that belong to the first two quartiles and the other $25 \%$ from the rest.
} 
of SCC, but it is also explained by the classical strategy of ignoring the other side in order to minimise the debate. The creation of this account was promoted by unionist leaders who - unconvinced that the strategy of ignoring the debate was adequate - claimed to speak up to defend Catalonia as an integral part of Spain. The wide gap in the number of followers of each account reflects in part the age difference as well as the difference in popular support ${ }^{3}$.

To start with these two accounts has allowed us to extract a random sample of followers less likely to be biased than filtering by hashtags. We have designed a stratified random selection of followers from the two main accounts that structure the debate, extracting the same number of users from each opinion community, to keep the balance between both sides and ensure the robustness of the results.

\section{Measuring the position in the debate}

From each tweet-reply we have collected information at three different levels, i.e. (i) the replier who sends the tweet, (ii) the interactions between the replier and the addressee/s of the tweet, and the (iii) conversation in which the tweet is inserted.

The content of each reply has been manually coded to determine whether users were actually talking about the issue of independence. Tweets that were issue-related have been examined, in the context of the conversations they belonged to, and coded according to parameters such as the length and the dominant topic of discussion. To guarantee the reliability of the coding process, several tests have been undertaken with the collaboration of external coders ${ }^{4}$. Both repliers and addressees have been manually classified as pro-independence, pro-union or neutral/undefined, based on information available in the profile description and Twitter timeline. By clarifying the position of the nodes and excluding neutral and non-identified users, we have been able to distinguish homogenous interactions from heterogeneous ones as well as differentiate between homogenous and heterogeneous conversations.

Interactions are the connections between two nodes (i.e. the replier and the addressee of the reply). Homogenous or intra-group interactions involve users who share the same position in the debate, while heterogeneous or inter-group interactions involve the contact between two users with opposing views. Interactions form part of more complex communicative structures, i.e. conversations, which potentially involve a continuous exchange of arguments, opinions and ideas. Conversations can be very short (e.g. containing only one reply), but they can also encompass complex dialogues involving several users and a relatively high number of interactions and references (links, photos, maps, etc.) and so on. We define heterogeneous conversations as those containing at

\footnotetext{
$\overline{3}$ The ANC account, created in 2011, has ten times more followers (138k against 13.9k) than the SCC one, created in 2014. Information checked on 02.09.2015.

${ }^{4}$ Tests consisted of comparing the level of agreement between coders ( $\mathrm{n}=3$ ), using Krippendorff's alpha (Hayes et al., 2007), for a random sample of tweets (whether they are issue-related or not), users (by differentiating between pro and against supporters) and conversations (by identifying the dominant topic of discussion). The results show an acceptable level of agreement in specifying tweets $(\alpha=0.95)$ as well as the users' position in the debate $(\alpha=0.94)$, while the identification of the dominant topic has achieved less consensus $(\alpha=0.74)$, due to the unavoidable degree of complexity and subjectivity involved in the process of coding groups of tweets.
} 
least one user with an opposing point of view, while homogenous conversations involve only individuals who share the same position.

Additionally, we have also gathered information on the accounts followed by the users in our sample. On Twitter, users decide to follow whom they want to hear from. That is a powerful filter that provides information on the user's interests and preferences (Bode, 2016). This structure determines which tweets are displayed on the user's timeline and, therefore, the primary informative content $s /$ he is exposed to. Users tend to follow other users who are following them - a norm of reciprocity is part of the netiquette rules on Twitter; especially if there is some affinity. This reinforces the appearance of homophily (Lazarsfeld et al., 1954; Huberman et al., 2008).

We have generated an indicator to locate the following behaviour of each user along a continuum. Extreme values in this indicator show a stronger affinity with one of the two sides. This measure can be understood as a proxy for the degree of homophily of the user's following behaviour.

To build this indicator, we have taken into consideration the most popular Twitter accounts among followers of ANC and SCC, listing the 100 most-followed accounts for each group. The algorithm clearly discriminates the most influential accounts since the level of overlapping is rather low, showing that both publics have different referents. The seminal accounts of each group are relevant key actors in the Catalan/Spanish public sphere, such as journalists, the media, politicians, political activists, political institutions, political parties, sportsmen, etc. By counting which of these seminal accounts were followed by each of the users in our samples, we have generated a matrix and summarised the information in an indicator that synthesises one's following behaviour, i.e. whether one is more inclined towards one pole or the other, or a mixture of both. This indicator has been built applying MDS (multidimensional scaling), where following an account indicates proximity to this account. The individual value of each account in the bidimensional solution gives its relative distances to the seminal accounts in a common space. This strategy methodologically differs from the Bayesian estimation proposed by Pablo Barberá (2015), but is similar in spirit. The main difference is related to the fact that we do not take into account the total number of accounts following each user to weight the relative importance of the seminal accounts followed.

\section{Description of the data}

Overall, our sample ( $\mathrm{N}=1,500$ replies) contains 2,762 interactions, sent by 526 repliers. Each interaction involves a tweet written by a replier and addressed to a poster. There can be other addressees together with the original poster, since the reply can also target additional users, which explains why the number of addressees is higher than the number of repliers. After dividing repliers into pro-independence and pro-union supporters, issue-related interactions can be aggregated into 259 different conversations. 
Table 1. Number of interactions, repliers, addressees and conversations in the sample

\begin{tabular}{lll} 
& Total & Issue related \\
\hline Interactions & 2,762 & $724(26 \%)$ \\
Repliers & 526 & $144(27 \%)$ \\
Addressees & 1,954 & $448(23 \%)$ \\
Conversations & - & 259 \\
\hline
\end{tabular}

Approximately $1 / 4$ of the users and interactions in our sample are related to the debate on independence. Although some users are specialised and focused on a single issue (especially if they are militantly committed), Twitter users tend to manifest a plurality of different interests. They can talk about a wide range of topics, and it is very usual to change from one to another. That is the reason why, despite selecting users interested in the debate, we have captured many tweets and interactions not actually connected with the issue under consideration, which have been excluded from the analysis.

\section{ANALYSIS}

\section{Characterising the two sides of the debate}

Regardless of the side of the debate they favour, users who reply on the issue of independence are rather active ones. They frequently post information on Twitter (an average of 10 posts per day), and a relatively high proportion of them (22\%) link their account to a blog or webpage. These users, for whom Twitter involvement is a way to channel their political activism, are likely to be 'influentials', better informed and more interested and aware of politics than the average citizen (the classical formulation of the hypothesis of the influentials can be found in Katz et al., 1955; updated in Keller et al., 2003; although Watts, 2007).

Differences between both opinion communities can be grouped into three main areas, i.e. the following behaviour, the location and language of communication, and the intensity of Twitter activity on this issue.

First, individuals who share similar political views on the issue tend to exhibit a similar pattern of preferences in their following behaviour compared to individuals on the opposite side of the debate (see Figure 1). The area of intersection between both communities is rather small, whereas the extremes are more populated. This evidence supports the hypothesis of a "natural" tendency towards homophily in social networks, i.e. a major propensity to follow accounts and form networks that are more consistent with one's own position. The user's following behaviour thereby becomes a good predictor of the position in the debate, as both variables are highly correlated.

Second, pro-independence repliers are mostly located in Catalonia and tend to use Catalan as the language of communication (69\%). Even though pro-union repliers are 
mostly located in Catalonia, a considerable proportion of them are also located in other parts of Spain. The language used by pro-union repliers in their communications is mainly Spanish (67\%). As survey studies have repeatedly shown, although the recent support for independence in Catalonia is not related perfectly with having Catalan as a mother tongue and there is even remarkable support among respondents with a Spanish and Catalan dual identification (e.g. Serrano, 2013), it is also clear that there is a relation between the language spoken, national identity and the degree of support for independence.

Third, although pro-independence users only represent $54 \%$ of the total amount of issue-related repliers, they produce $2 / 3$ of the interactions, while pro-union repliers produce only $1 / 3$ (see Figure 2). Intra-group dialogue is relatively more frequent on the pro-independence side, whereas inter-group dialogue becomes relatively more important on the pro-union side. This asymmetry is hardly surprising, as the pro-independence side is the "active" one and has the burden of proving that the status quo has to be changed and that it is possible to do it. Meanwhile the pro-union side is the "reactive" one, and has only to disqualify the arguments of the other side, showing the risks independence incurs - arguably, on this side, there is a less acute need to prove the general desirability of the world as it is.

Pro-independence mobilisation has been more numerous and crowded, sharing the characteristics of social movements which explains the more intense level of interactions. There is also much internal debate, as the pro-independence side is a coalition of diverse ideological positions ranging from the alternative left to the conservative right. Much energy is spent on reinforcing a network of mobilised supporters and trying to expand it by crossing lines.

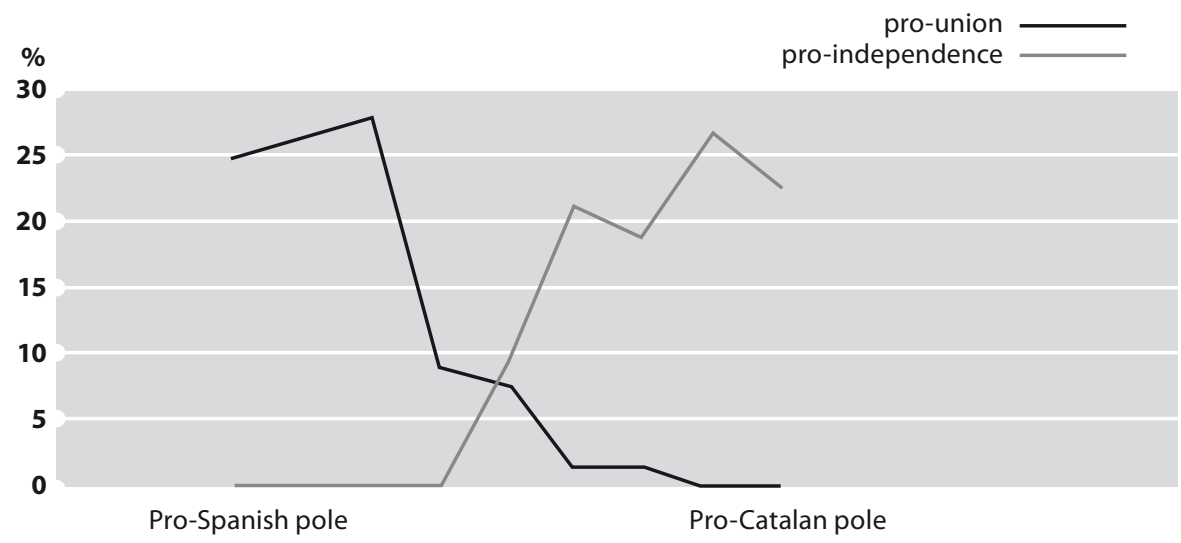

$\Delta$ Figure 1 .

Distribution of the users of both opinion communities according to their following behaviour (more pro-Spanish following behaviour on the left and more pro-Catalan following behaviour on the right) $\mathrm{N}=144$ repliers 
In contrast, defenders of the status quo have less incentive to be active in the debate. This disinterest is in part the result of the unionist strategy focused on minimising the issue, and discrediting its value by considering it an illegal cause. Pro-union supporters tend to talk between themselves about other political issues, not the secession of Catalonia. Comparatively, they are more focused on replying to pro-independence users than internally discussing the issue (see Figure 2).

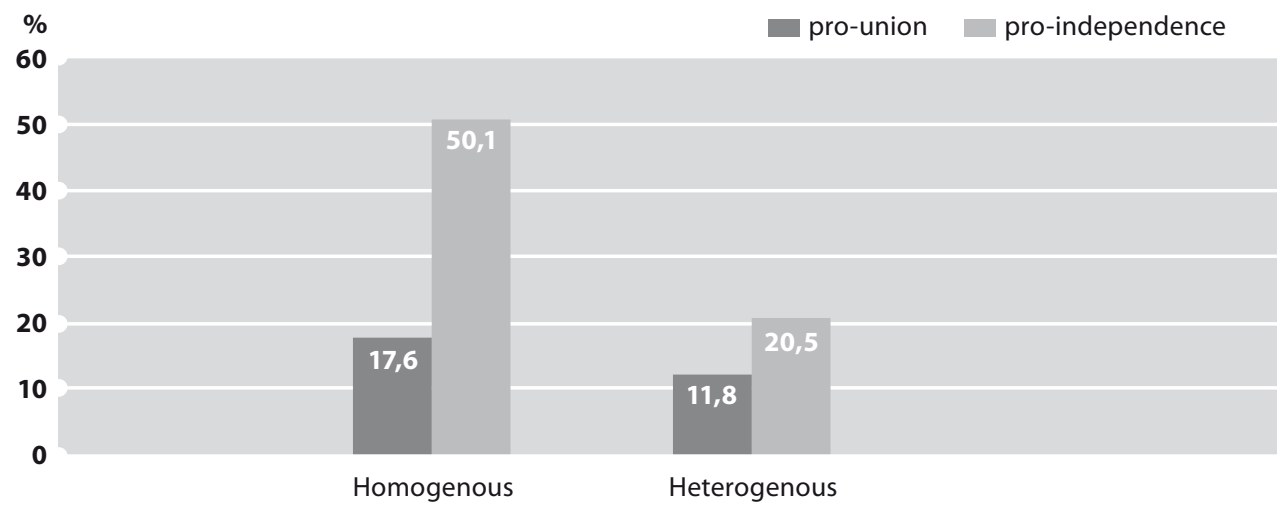

A Figure 2.

Percentage of homogenous and heterogeneous interactions by opinion community

\section{Cross-communication between opinion communities}

If, in terms of following behaviour, both opinion communities clearly differ from each other, forming two separate and polarising poles, there is much cross-talking between these two blocks. In fact, $40 \%$ of conversations contain heterogeneous interactions, which indicates a certain willingness to cross political lines and discuss with individuals holding opposing viewpoints.

Some evidence points to the existence of a genuine deliberative effort to debate with the other side. In heterogeneous interactions, there is an effort to adapt oneself to the linguistic behaviour of the other. In terms of language, intra-group interactions are mostly written in the dominant language of each opinion community: $75 \%$ in Catalan on the pro-independence side, and $75 \%$ in Spanish on the pro-union side. Significantly, these percentages are lower in heterogeneous interactions, decreasing to $64 \%$ and $56 \%$ respectively. Even more interestingly, conversations between opposing views tend to be longer compared to homogeneous ones, which can be regarded as a symptom of deliberative engagement.

Heterogeneous conversations tend to be more controversial, tense and confrontational than homogeneous ones. This can be confirmed observationally by the thematic orientation of tweets (more focused on controversial and divisive issues) and the tone of the conversation (more pugnacious). However, this more confrontational environment 
also coexists with the development and the exchange of rational arguments. This finding is consistent with a more positive assessment of new social media, which in fact enable the emergence of a more complex political life. Remarkably, heterogeneous conversations tend to be significantly longer than homogenous ones (see Figure 3). Heterogeneous conversations are expected to be longer especially if they are based on the exchange of arguments, since confronting, balancing and discussing the premises of the debate requires a more intensive and demanding dialogical activity. Discussions in homogenous debates, in which participants agree and sympathise with the ideas, are instead more likely to be less extensive.

Thematic interests and priorities vary depending on the nature of the conversation (see Table 2). Heterogeneous conversations focus on confrontational and divisive issues such as identity and ethno-linguistics. The debates on the definition of "nation" in terms of who has the right to decide what and the use of the language are present. These debates are mainly focused on drawing the lines between "us" and "them".

On the pro-union side, language is used as the defining boundary between the two communities dividing Catalan society into two parts (between Catalan-speakers and Castilian-speakers) and accusing the pro-independence side of language discrimination. This typical wedge issue (Hillygus et al., 2014) tries to divide the Spanish-origin community between their cultural loyalty and their loyalty to their host community. Pro-independence homogeneous conversations are more focused on the dimension of politics in a broader sense (political mobilisation, political actors, etc.), with the aim of reinforcing and mobilising as widespread support as possible for a social coalition. This strategic necessity of maximal inclusivity explains the dominance on the pro-independence side of a civiclike nationalism that minimises ethnic nationalism. On both sides there is special interest in the media. Both sides are very critical with the media aligned with the opposite side, with frequent accusations of partisanship and manipulation by the political institutions. This issue is comparatively more prominent in pro-union homogenous conversations, where the debate on independence is usually attributed to the mass manipulation of political preferences carried out through the media and the school system.

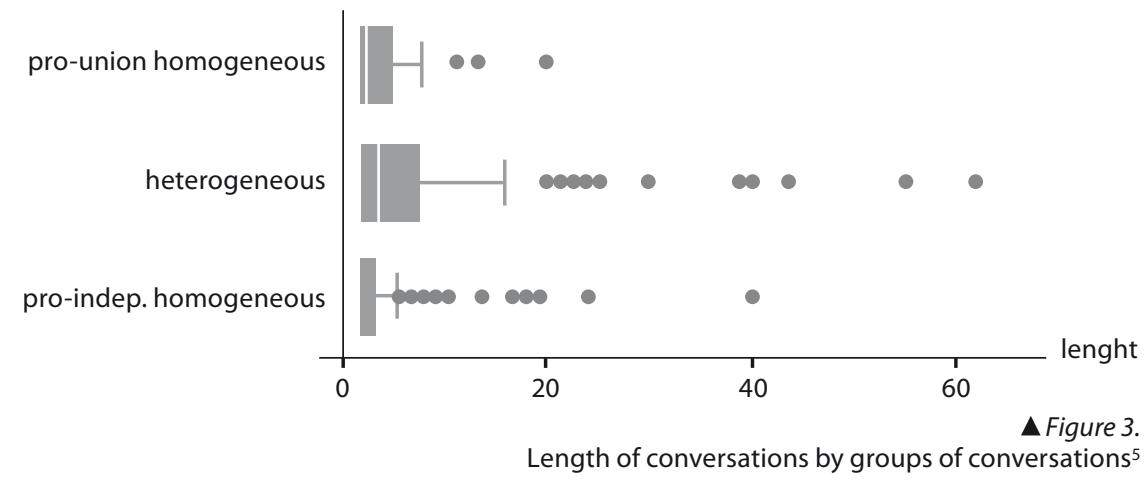

\footnotetext{
$\overline{5}$ The difference in means between the length of heterogeneous and homogeneous conversations is significant at the $95 \%$ confidence level in a comparison of means tests (t-test).
} 
Table 2. Length (mean number of tweets) and dominant topic of discussion by groups of conversations

\begin{tabular}{lllll} 
& $\begin{array}{l}\text { Pro-union } \\
\text { homogeneous } \\
(\mathbf{2 0 \% )}\end{array}$ & $\begin{array}{l}\text { Heterogeneous } \\
(\mathbf{4 0 \% )}\end{array}$ & $\begin{array}{l}\text { Pro-independence } \\
\text { homogeneous } \\
(\mathbf{4 0 \% )}\end{array}$ & Total \\
\hline $\begin{array}{l}\text { Length (mean) } \\
\text { Topic (\%) }\end{array}$ & 4.4 & 8.5 & 4.5 & 6.1 \\
\hline $\begin{array}{l}\text { Ethnolinguistic } \\
\text { Politics }\end{array}$ & 31.4 & 37.5 & 20.2 & 29.3 \\
Media/manipulation & 45.1 & 40.4 & 61.5 & 49.8 \\
Other & 23.5 & 14.4 & 16.3 & 17.0 \\
\hline
\end{tabular}

\section{CONCLUSIONS}

Despite being clustered around two distinct poles, Twitter users on opposite sides of the debate on the independence of Catalonia frequently interact with each other and cross lines to exchange arguments and opinions. Although these interactions tend to be more pugnacious and confrontational than interactions among individuals with similar ideas, they do not exclude a genuine exchange of argument. Heterogeneous conversations tend to be longer than homogeneous ones, partly because these dialogues require further involvement and more intense dialogical activity in order to discuss the premises of the debate and participate in a dynamics of arguments and counterarguments.

With the data at hand, we cannot measure the impact of these communications on the user's behaviour (for instance, in terms of ideological or political polarisation). That would require a longitudinal analysis of the behaviour of the users or an experimental setting to be tested. However, it is possible to speculate that a more rational exchange of arguments is likely to have certain de-polarising effects, at least in the sense of recognising the "other side", not as an enemy, but as a valid interlocutor with whom it is possible to exchange views in a reasonable way. Some of the long conversations we have analysed point in this direction, as some users, in spite of seriously disagreeing, end by congratulating each other on the discussion.

Even in a potentially polarised issue such as secession, these results point to the possibility of social media as a locus for serious deliberation between opposing sides. Against the hypothesis that associates the Internet with the threat of segregated and fragmented opinion islands, social media can positively contribute to open new deliberative public spaces where arguments and ideas can actually be discussed and contrasted across lines of political difference. There is, however, the need to investigate further the motivations and the incentives that can lead individuals to engage with other users in such a way. For future research, we plan to both extend the study to a longer period of time and delve into the dynamics of conversation, by providing a deeper analysis on the discursive interaction between users through a more qualitative research strategy. 


\section{References}

>Adamic, Lada A. and Glance, Natalie (2005) The Political Blogosphere and the 2004 US Election: Divided They Blog, pp. 36-43 in Proceedings of the 3rd International Workshop on Link Discovery. New York: ACM.

>Bächtiger, André, Niemeyer, Simon, Neblo, Michael, Steenbergen, Marco R. and Steiner, Jürg (2010) Disentangling Diversity in Deliberative Democracy: Competing Theories, Their Blind Spots and Complementarities. Journal of Political Philosophy 18 (1): 32-63. DOI: 10.1111/j.1467-9760.2009.00342.x.

>Barberá, Pablo (2015) Birds of the Same Feather Tweet Together: Bayesian Ideal Point Estimation Using Twitter Data. Political Analysis 23 (1): 76-91. DOI: 10.1093/pan/mpu011.

>Bode, Leticia (2016) Pruning the News Feed: Unfriending and Unfollowing Political Content on Social Media. Research \& Politics 3 (3): 1-8. DOI: 10.1177/2053168016661873.

$>$ Colleoni, Elanor, Rozza, Alessandro and Arvidsson, Adam (2014) Echo Chamber or Public Sphere? Predicting Political Orientation and Measuring Political Homophily in Twitter Using Big Data. Journal of Communication 64 (2): 317-332. DOI: 10.1111/jcom.12084.

>Conover, Michael, Ratkiewicz, Jacob, Francisco, Matthew, Gonçalves, Bruno, Menczer, Filippo and Flammini, Alessandro (2011) Political Polarization on Twitter, in Proceedings of the 5th International Conference on Weblogs and Social Media. Association for the Advancement of Artificial Intelligence. http://www.aaai.org/ocs/index.php/ICWSM/ICWSM11/paper/download/2847/3275 (14.01.2013).

$>$ Dertouzos, Michael L. (1991) Communications, Computers and Networks. Scientific American 265 (3): 62-69. DOI: 10.1038/scientificamerican0991-62.

>DiPrete, Thomas A., Gelman, Andrew, McCormick, Tyler, Teitler, Julien and Zheng, Tian (2011) Segregation in Social Networks Based on Acquaintanceship and Trust. American Journal of Sociology 116 (4): 1234-83. DOI: 10.1086/659100.

>Dryzek, John S. (2000) Deliberative Democracy and Beyond: Liberals, Critics, Contestations. Oxford: Oxford University Press. DOI: 10.1093/019925043X.001.0001 (edition 2002).

>Ess, Charles (1996) The Political Computer: Democracy, CMC, and Habermas, pp. 197-230, in Ess, Charles (ed.) Philosophical Perspectives on Computer-mediated Communication. Albany: State University of New York Press.

>Fishkin, James S. (1991) Democracy and Deliberation: New Directions for Democratic Reform. New Haven \& London: Cambridge University Press.

$>$ Garrett, R. Kelly, Gvirsman, Shira Dvir, Johnson, Benjamin K., Tsfati, Yariv, Neo, Rachel and Dal, Aysenur (2014) Implications of Pro-and Counterattitudinal Information Exposure for Affective Polarization. Human Communication Research 40 (3): 309-332. DOI: 10.1111/hcre.12028.

$>$ Gonzalez-Bailon, Sandra, Kaltenbrunner, Andreas and Blanchs, Rafael E. (2010) The Structure of Political Discussion Networks: A Model for the Analysis of Online Deliberation. Journal of Information Technology 25 (2): 1-14. DOI: 10.1057/jit.2010.2.

$>$ Graham, Todd (2008) Needles in a Haystack: A New Approach for Identifying and Assessing Political Talk in Nonpolitical Discussion Forums. Javnost/The Public 15 (2): 17-36. DOI: 10.1080/13183222.2008.11008968.

$>$ Graham, Todd and Witschge, Tamara (2006) In Search of Online Deliberation: Towards a New Method for Examining the Quality of Online Discussions. Communications 28 (2): 173-204. DOI: 10.1515/comm.2003.012 (EDITION 2006 ONLINE).

$>$ Guibernau, Montserrat (2013) Secessionism in Catalonia: After Democracy. Ethnopolitics 12 (4): 368-393. DOI: 10.1080/17449057.2013.843245.

>Habermas, Jürgen (1985) The Theory of Communicative Action: Reason and the Rationalization of Society. Boston: Beacon Press.

$>$ Hayes, Andrew F. and Krippendorff, Klaus (2007) Answering the Call for a Standard Reliability Measure for Coding Data. Communication Methods and Measures 1 (1): 77-89. DOI: 10.1080/19312450709336664. 
>Hillygus, D. Sunshine and Shields, Todd G. (2014) The Persuadable Voter: Wedge Issues in Presidential Campaigns. Princeton and Oxford: Princeton University Press. DOI: 10.1515/9781400831593 (EDITION 2008).

>Holbert, R. Lance, Garrett, R. Kelly and Gleason, Laurel S. (2010) A New Era of Minimal Effects? A Response to Bennett and lyengar. Journal of Communication 60 (1): 15-34. DOI: 10.1111/j.1460-2466.2009.01470.x.

>Huberman, Bernardo A., Romero, Daniel M. and Wu, Fang (2008) Social Networks That Matter: Twitter Under the Microscope. Rochester, NY: Social Science Research Network. DOI: 10.2139/ ssrn.1313405.

>Katz, Elihu and Lazarsfeld, Paul F. (1955) Personal Influence: The Part Played by People in the Flow of Mass Communications. New York: Free Press.

>Keller, Edward and Berry, Jonathan (2003) The Influentials: One American in Ten Tells the Other Nine How to Vote, Where to Eat, and What to Buy. New York: Free Press.

>Lazarsfeld, Paul F. and Merton, Robert K. (1954) Friendship as a Social Process: A Substantive and Methodological Analysis. Freedom and Control in Modern Society 18 (1): 18-66.

>Mansbridge, Jane (1999) Everyday Talk in the Deliberative System, pp. 211-239 in Macedo, Stephen (ed.) Deliberative Politics: Essays on Democracy and Disagreement. Oxford University Press.

$>$ McPherson, Miller, Smith-Lovin, Lynn and Cook, James M. (2001) Birds of a Feather: Homophily in Social Networks. Annual Review of Sociology (27): 415-444. DOI: 10.1146/annurev.soc.27.1.415. $>$ Muñoz, Jordi and Guinjoan, Marc (2013) Accounting for Internal Variation in Nationalist Mobilization: Unofficial Referendums for Independence in Catalonia (2009-11). Nations and Nationalism 19 (1): 44-67.

$>$ Mutz, Diana C. (2006) Hearing the Other Side: Deliberative Versus Participatory Democracy. Cambridge, New York: Cambridge University Press. DOI: 10.1017/CBO9780511617201.

>Orriols, Lluis and Rodon, Toni (2016) The 2015 Catalan Election: The Independence Bid at the Polls. South European Society and Politics 21 (3): 1-23. DOI: 10.1080/13608746.2016.1191182.

$>$ Rambukkana, Nathan (2015) Hashtag Publics: The Power and Politics of Discursive Networks. New York: Peter Lang Publishing. DOI: 10.3726/978-1-4539-1672-8.

>Rheingold, Howard (1993) The Virtual Community: Homesteading on the Electronic Frontier. Reading, Mass: Addison-Wesley.

$>$ Rico, Guillem and Liñeira, Robert (2014) Bringing Secessionism into the Mainstream: The 2012 Regional Election in Catalonia. South European Society and Politics 19 (2): 257-280. DOI: 10.1080/13608746.2014.910324.

>Ruiz, Carlos, Domingo, David, Micó, Josep Lluís, Díaz-Noci, Javier, Meso, Koldo and Masip, Pere (2011) Public Sphere 2.0? The Democratic Qualities of Citizen Debates in Online Newspapers. The International Journal of Press/Politics 16 (4): 463-487. DOI: 10.1177/1940161211415849.

$>$ Serrano, Ivan (2013) Just a Matter of Identity? Support for Independence in Catalonia. Regional \& Federal Studies 23 (5): 523-545. DOI: 10.1080/13597566.2013.775945.

>Small, Tamara A. (2011) What the Hashtag? Information, Communication \& Society 14 (6): 872-895. DOI: 10.1080/1369118X.2011.554572.

>Steenbergen, Marco R., Bächtiger, André, Spörndli, Markus and Steiner, Jürg (2003) Measuring Political Deliberation: A Discourse Quality Index. Comparative European Politics 1 (1): 21-48. DOI: 10.1057/palgrave.cep.6110002.

>Stromer-Galley, Jennifer (2007) Measuring Deliberation's Content: A Coding Scheme. Journal of Public Deliberation 3 (1): 1-37.

>Stromer-Galley, Jennifer, Bryant, Lauren and Bimber, Bruce (2015) Context and Medium Matter: Expressing Disagreements Online and Face-to-Face in Political Deliberations. Journal of Public Deliberation 11 (1): 1-22.

>Sunstein, Cass R. (2002) The Law of Group Polarization. Journal of Political Philosophy 10 (2): 175-195. 
IZVORNI ZNANSTVENI RAD / DOI: 10.20901/ms.7.14.9 / PRIMLJENO: 07.03.2016.

$>$ Watts, Duncan (2007) Challenging the Influentials Hypothesis. WOMMA Measuring Word of Mouth 3 (4): 201-211.

$>$ Wright, Scott and Street, John (2007) Democracy, Deliberation and Design: The Case of Online Discussion Forums. New Media \& Society 9 (5): 849-869. DOI: 10.1177/1461444807081230.

$>$ Yardi, Sarita and Boyd, Danah (2010) Dynamic Debates: An Analysis of Group Polarization over Time on Twitter. Bulletin of Science, Technology \& Society 30 (5): 316-327. DOI:

10.1177/0270467610380011. 


\section{TVITANJE O KATALONSKOJ NEZAVISNOSTI: DINAMIKA POLITIČKE RASPRAVE I POLARIZACIJE SKUPINA}

Joan Balcells :: Albert Padró-Solanet

SAŽETAK Ovaj rad pruža dokaze koji govore u prilog tome da društveni mediji omogućavaju javnu deliberaciju, što je u suprotnosti s hipotezom koja naglašava dominaciju učinka "eho-komore". Rad se bavi konverzacijskim interakcijama na Twitteru između podupiratelja suprotstavljenih strana u debati o katalonskoj nezavisnosti. Ta tema, o kojoj mišljenja mogu biti snažno polarizirana, upotrijebljena je za studiju slučaja. Istraživanje je provedeno na slučajnom uzorku komunikacija na Twitterovoj platformi za odgovore i uključuje zagovornike i protivnike nezavisnosti. Unatoč tendenciji stvaranja "homofilnih mreža" koje okupljaju ljude sličnih stavova, utvrdili smo da je komunikacija između suprotstavljenih političkih tabora relativno česta. Nadalje, heterogene konverzacije (u kojima se suprotstavljene strane upuštaju u dijalog) značajno su duže nego homogene (u kojima svi sudionici dijele isto mišljenje), što se može smatrati znakom prave deliberacije, utemeljene na racionalnoj razmjeni argumenata između suprotstavljenih perspektiva.

KLJUČNE RIJEČI

Bilješka o autorima

Joan Balcells :: Faculty of Law and Political Science, Open University of Catalonia, Barcelona, Španjolska :: jbalcells@uoc.edu

Albert Padró-Solanet :: Faculty of Law and Political Science, Open University of Catalonia, Barcelona, Španjolska :: apadro_solanet@uoc.edu 